\title{
Altered placental expression of kisspeptin and its receptor in pre-eclampsia
}

\author{
Judith E Cartwright and Paula Juliet Williams ${ }^{\mathbf{1}}$ \\ Division of Biomedical Sciences, St George's University of London, Cranmer Terrace, London SW17 ORE, UK \\ ${ }^{1}$ Human Genetics Research Group, School of Molecular and Medical Sciences, Queen's Medical Centre, University of Nottingham, \\ A Floor West Block, Nottingham NG7 2UH, UK \\ (Correspondence should be addressed to P J Williams; Email: paula.williams@nottingham.ac.uk)
}

\begin{abstract}
Kisspeptin, originally identified as metastatin, important in preventing cancer metastasis, has more recently been shown to be important in pregnancy. Roles indicated for kisspeptin in pregnancy include regulating trophoblast invasion and migration during placentation. The pregnancy-specific disorder pre-eclampsia (PE) is now accepted to begin with inadequate trophoblast invasion and the current study therefore sets out to characterise placental expression of both kisspeptin (KISS1) and its receptor (KISS1R) throughout pregnancy and in PE. Placental tissue was obtained from women undergoing elective surgical termination of early pregnancy $(n=10)$ and from women following Caesarean section at term in normal pregnancy $(n=10)$ and with PE $(n=10)$. Immunohistochemistry of paraffin embedded sections and western immunoblotting were performed to
\end{abstract}

assess protein localisation and expression. Quantitative realtime PCR was carried out to evaluate mRNA expression of both KISS1 and KISS1R. Protein and mRNA expression was found to mirror each other with KISS1 expression found to be reduced in PE compared with that in normal term pregnancy. Interestingly, KISS1R expression at both the mRNA and protein levels was found to be increased in PE compared with that in normal term pregnancy. The current findings of increased KISS1R expression may represent a mechanism by which functional activity of KISS1 is higher in PE than in normal pregnancy. Higher levels of activity of KISS1R may be involved in inhibition of trophoblast invasion and angiogenesis, which are associated with PE.

Journal of Endocrinology (2012) 214, 79-85

\section{Introduction}

The primary translation product of KISS1 is a 145 amino acid polypeptide known as Kp-145. Kisspeptins (KISS1), which are biologically active, containing 54 (Kp-54), 14 (Kp-14), $13(\mathrm{Kp}-13)$ and ten $(\mathrm{Kp}-10)$ amino acids, are then produced by post-translational cleavage of $\mathrm{Kp}-154$. All kisspeptins share an Arg-Phe- $\mathrm{NH}_{2}$ motif at the C-terminus, which is required for biological activity (Roa et al. 2008). The activity of KISS1 is regulated via the expression of the KISS1 receptor (KISS1R), an orphan G-protein-coupled receptor GPR54 (Ohtaki et al. 2001).

The KISS1 gene was originally identified as a human metastasis suppressor gene; however, additional roles have now been revealed including a fundamental role in reproductive function. Kisspeptins are known to be involved in the onset of puberty due to their role in stimulating hypothalamic GNRH release, being described as the gatekeeper of reproductive function (Seminara et al. 2003). Mutations in the KISS1 gene have been shown to be associated with the onset of precocious puberty and hypogonadotropism (Luan et al. 2007), whereas inactivating mutations in KISS1R result in failure to progress through puberty (de Roux et al. 2003). In addition to their central control of the gonadotrophic axis, KISS1 has been found to be important in placentation, pregnancy and cardiovascular function (Bilban et al. 2004, Hiden et al. 2007, Mead et al. 2007b). The physiological importance of KISS1 is further verified by the observations that KISS1R is expressed in a variety of human tissues including hypothalamus, placenta, aorta, coronary artery and umbilical vein (Janneau et al. 2002, Mead et al. 2007a).

Of particular importance to placentation is the involvement of KISS1 in cell migration, a process which is of crucial importance for trophoblast invasion. KISS1 has been shown to induce focal adhesion and stress fibre formation and also to phosphorylate focal adhesion kinase and paxillin, the intracellular signals needed for cell migration, which may associate with integrins to inhibit migration (Ohtaki et al. 2001). Furthermore, KISS1 has also been shown to diminish matrix metalloproteinase 9 (MMP9) expression by reduced NFKb (NFKB1) binding of the MMP9 promoter, thereby resulting in a reduction of cell migration (Yan et al. 2001). It is specifically $\mathrm{Kp}-10$, produced by first trimester 
trophoblast cells, that has been shown to inhibit migration (Bilban et al. 2004).

An important role for KISS1 in pregnancy has also been suggested due to the dramatic increase in circulating KISS1 levels in pregnancy (Horikoshi et al. 2003). Furthermore, a placental origin for the peptide has been suggested due to the observation that circulating KISS1 levels fall 5 days post-delivery compared with non-pregnant concentrations. However, the exact function for such an elevation within the gonadotrophin axis remains to be determined as LH levels are not elevated in pregnancy as would be predicted by the observed potent stimulation of LH following exogenous administration of KISS1 (Dhillo et al. 2006).

KISS1 is present at the feto-maternal interface with abundant expression in the syncytiotrophoblast cells (Bilban et al. 2004). KISS1R expression has been localised to both the villous and invasive extravillous cytotrophoblast cells (EVT; Bilban et al. 2004). Interestingly mRNA and protein expressions of both KISS1 and KISS1R have been shown to be higher in first trimester placental trophoblast cells than in term gestation, contrasting with the increasing circulating KISS1 levels during pregnancy (Horikoshi et al. 2003, Bilban et al. 2004). This finding of the highest levels of expression of KISS1 and KISS1R in early pregnancy coincides with the time of maximal extravillous cytotrophoblast invasion and has therefore been suggested to represent a crucial control mechanism regulating placental development (Bilban et al. 2004). It is therefore suggested that altered placental expression of KISS1 and/or KISS1R may be associated with poor placentation and the associated disorder of preeclampsia (PE). Further support for this comes from the observation of lower circulating KISS1 concentrations in early second trimester serum samples from women who subsequently develop PE and intra-uterine growth restriction (Armstrong et al. 2009).

The objective of the current study was to investigate the expression of KISS1 and KISS1R in PE. The hypothesis to be tested was that the increased expression of KISS1 and/or KISS1R will be associated with PE.

\section{Materials and Methods}

After local ethical committee approval and with appropriate informed consent, placental tissue was obtained from women undergoing elective surgical termination of pregnancy (TOP) during early pregnancy $(n=10$; gestational age (obtained from last menstrual period) $8 \cdot 8 \pm 0 \cdot 9$ weeks (mean \pm s.D. $))$ and at delivery in the third trimester from ten women with normal term pregnancy (gestational age 39.4 $\pm 1 \cdot 1$ weeks) and ten women with PE (gestational age $37 \cdot 6 \pm 2 \cdot 6$ weeks). Term samples from both with normal pregnancy and PE were obtained from women undergoing elective Caesarean section prior to labour. Additional early pregnancy placental samples were collected at St George's University of London (London, UK) with ethical approval from Wandsworth
Local Ethics Committee. Doppler ultrasound screening can characterise pregnancies into distinct groups, reflecting a proxy measure of the extent to which remodelling of the spiral arteries has occurred (Prefumo et al. 2004, Whitley et al. 2007). Maternal uterine artery Doppler velocimetry scans were taken in the Fetal Medicine Unit, St George's Hospital from women attending the clinic for elective TOP as previously described (Prefumo et al. 2004). High-resistance cases were defined as those with bilateral uterine diastolic notches and a mean resistance index $(\mathrm{RI})>95$ th percentile. Normal resistance cases had no diastolic notches and a mean RI $<95$ th percentile. These resistance groups represent cases most (high RI; $n=6$; gestational age $11 \cdot 2 \pm 0 \cdot 4$ weeks) and least (normal RI; $n=6$; gestational age $11 \cdot 1 \pm 0 \cdot 3$ weeks) likely to have developed PE had the pregnancy progressed (Melchiorre et al. 2008, Poon et al. 2009).

All women with PE met the International Society for the Study of Hypertension in Pregnancy definition (Brown et al. 2001). Clinical data for normal term pregnancy and PE subjects are shown in Table 1. Biopsies for immunohistochemistry were fixed in formalin, embedded in wax, and $5 \mu \mathrm{M}$ serial sections were prepared. Biopsies of placental tissue, collected for RNA extraction, were snap frozen and stored at $-80{ }^{\circ} \mathrm{C}$.

\section{Immunohistochemistry}

Single immunohistochemical labelling was carried out using the Dako REAL EnVision detection system (Dako UK Ltd, Cambridgeshire, UK). The sections were first deparaffinised by immersion in xylene followed by rehydration by passing through descending concentrations of alcohol (100-70\%) and finally immersion in running tap water. Antigen retrieval was performed by microwave heating these sections for $10 \mathrm{~min}$ in trisodium citrate buffer $(10 \mathrm{mM}$ sodium citrate, $\mathrm{pH} 6 \cdot 0)$. Peroxidase block solution (Dako) was applied to sections for $5 \mathrm{~min}$ to block endogenous peroxidase activity. To reduce non-specific background staining, Ultra V Block

Table 1 Clinical details of term pregnancy subject groups. Data are expressed as mean (s.D.)

\begin{tabular}{|c|c|c|c|}
\hline & $\begin{array}{c}\text { Normal term } \\
\text { pregnancy }\end{array}$ & Pre-eclampsia & $P$ value \\
\hline Number of subjects & 10 & 10 & NA \\
\hline Maternal age (years) & $28(7 \cdot 6)$ & $32(9 \cdot 6)$ & NS \\
\hline Maternal BMI $\left(\mathrm{kg} / \mathrm{m}^{2}\right)$ & $23 \cdot 2(3 \cdot 3)$ & $24 \cdot 3(4 \cdot 4)$ & NS \\
\hline $\begin{array}{l}\text { Gestational age } \\
\text { (weeks) }\end{array}$ & $38 \cdot 3(1 \cdot 8)$ & $36 \cdot 2(2 \cdot 1)$ & $<0 \cdot 05$ \\
\hline Baby weight (kg) & $3 \cdot 6(0 \cdot 9)$ & $3 \cdot 5(1 \cdot 08)$ & NS \\
\hline $\begin{array}{l}\text { Systolic blood } \\
\text { pressure }(\mathrm{mmHg})\end{array}$ & $111(18 \cdot 6)$ & $152(10 \cdot 5)$ & $<0 \cdot 000$ \\
\hline $\begin{array}{l}\text { Diastolic blood } \\
\text { pressure }(\mathrm{mmHg})\end{array}$ & $81(15 \cdot 7)$ & $110(15 \cdot 5)$ & $<0 \cdot 000$ \\
\hline Proteinuria (g/l) & NA & $1.9(1 \cdot 9)$ & NA \\
\hline Platelets $\left(\times 10^{9} / \mathrm{I}\right)$ & NA & $185(35 \cdot 9)$ & NA \\
\hline Creatinine $(\mu \mathrm{mol} / \mathrm{l})$ & NA & $66(7 \cdot 0)$ & NA \\
\hline
\end{tabular}


(Thermo Scientific, Cheshire, UK) was applied to the sections for $5 \mathrm{~min}$. Slides were then incubated for $1 \mathrm{~h}$ with appropriate mouse monoclonal antibody for either KISS1 (AbD Serotec, Oxford, UK; MCA3219Z; 1:50) or KISS1R (Novus Biologicals, Cambridge, UK; NLS1926; mouse monoclonal; $1: 100)$. Specificity of staining was confirmed using positive control tissue. Negative controls were also performed in each staining run using no primary antibody.

\section{Analysis of immunohistochemical labelling}

All slides were analysed by the same observer ( $\mathrm{P} \mathrm{J} \mathrm{W)}$ who was blinded to pregnancy stage or outcome. For analysis of placental sections, digital images of five randomly selected medium-power $(\times 200)$ fields were captured on NIS-Elements F2.20 (Nikon UK Ltd, Surrey, UK). As described previously, the total percentage of positive labelled cells per $\times 200$ magnification field was determined using the 'positive pixel count' function with ImageScope software (Aperio Technologies Ltd, Bristol, UK; Williams et al. 2010). Results are expressed as 'positivity' that takes into account both the number of positive pixels and the intensity of staining. A visual check was performed to ensure accurate discrimination of immunolabelled regions.

\section{RNA extraction}

Total RNA from placental biopsies (50-100 mg) was obtained using $1 \mathrm{ml}$ of Tri-reagent (Sigma) according to the manufacturer's instructions. RNA integrity was determined using an Agilent Bioanalyzer (Santa Clara, CA, USA) and all samples had an RNA integrity number $>8 \cdot 0$. RNA purity and concentration were verified using a Nanodrop spectrophotomer (Thermo Scientific); all RNA samples had an $A_{260} / A_{280}$ ratio of 1.85 or greater.

Following RNA extraction, $1 \mu \mathrm{g}$ of each sample was reverse transcribed to cDNA in a $20 \mu \mathrm{l}$ reaction using QuantiTect Reverse transcription kit (Qiagen). This kit contains a mix of random and oligo-dT primers thereby ensuring that cDNA is generated from all regions of RNA transcripts. The protocol also includes a genomic DNA elimination step prior to reverse transcription. Reverse transcription was performed using a Veriti 96-well thermal cycler (Applied Biosystems, Warrington, UK). The conditions used to generate first strand cDNA were $42{ }^{\circ} \mathrm{C}$ $(15 \mathrm{~min})$ and $95^{\circ} \mathrm{C}(3 \mathrm{~min})$. cDNA was diluted with nuclease-free water (Applied Biosystems) to a standard concentration of $1 \mu \mathrm{g} / \mu \mathrm{l}$ and stored at $-80{ }^{\circ} \mathrm{C}$ until use.

\section{Preparation of standards for quantitative real-time PCR}

Standards for KISS1, KISS1R and for the reference genes tyrosine 3-monooxygenase/tryptophan 5-monooxygenase activation protein, zeta (YWHAZ), hypoxanthine phosphoribosyltransferase 1 (HPRT) and succinate dehydrogenase subunit A $(S D H A)$ were made from cDNA obtained from a randomly selected control placenta using semi-quantitative PCR. QuantiTect Primer assays (Qiagen) were used to detect KISS1 (Hs_KISS1_1_SG; QT00016044; melting temperature $60{ }^{\circ} \mathrm{C}$ ) and KISS1R (Hs_KISS1R_1_SG; QT00043134; melting temperature $60^{\circ} \mathrm{C}$ ); sequence information for the primers in these kits is not available. The reference genes YWHAZ, HPRT and SDHA were assessed using oligonucleotide primers generating specific intron-spanning products (Table 2).

The PCR programme comprised an initial denaturation stage $\left(95^{\circ} \mathrm{C}, 15 \mathrm{~min}\right.$ ), amplification (stage I, $94{ }^{\circ} \mathrm{C}(30 \mathrm{~s})$; stage II, melting temperature $(30 \mathrm{~s})$; stage III, $\left.72{ }^{\circ} \mathrm{C}(1 \mathrm{~min})\right)$ and final extension $\left(72{ }^{\circ} \mathrm{C}, 7 \mathrm{~min} ; 8^{\circ} \mathrm{C}\right.$ 'hold'). Each PCR (final volume $50 \mu \mathrm{l}$ ) contained $23 \cdot 5 \mu \mathrm{l}$ nuclease-free water (Ambion, Grand Island, NY, USA); $25 \mu 12 \times$ ReddyMix PCR master mix containing $2.0 \mathrm{mM} \mathrm{MgCl}_{2}$ and $0.2 \mathrm{mM}$ of each dATP, dCTP, dGTP and dTTP (ThermoScientific, Abgene, Surrey, UK); 0.5 $\mu \mathrm{M}$ forward and reverse primers; and $1 \mu \mathrm{l}$ cDNA. The annealing temperature and cycle number of both primers were optimised and used in their linear range. Agarose gel electrophoresis $(2 \cdot 0-2 \cdot 5 \%)$ and ethidium bromide staining confirmed the presence of products at the expected sizes. The resulting PCR product was extracted (QIAquick gel extraction kit, Qiagen), sequenced, and results were cross-referenced with NCBI Nucleotide Blast to determine specificity of the target gene. After confirmation that the product was specific to the target gene, extracted PCR products were resuspended in nucleasefree water to allow preparation of a standard curve ranging from $10^{7}$ to $10^{1}$ copies $/ \mu$ l. Standards were stored at $-80{ }^{\circ} \mathrm{C}$ until its use in quantitative real-time PCR (qRT-PCR).

\section{$q R T-P C R$}

qRT-PCR was used to quantify the expressions of KISS1 and KISS1R relative to the reference genes YWHAZ, HPRT and $S D H A$. PCRs, set up in duplicate, were carried out in

Table 2 Primer sequences for reference genes used in quantitative RT-PCR

\begin{tabular}{|c|c|c|c|c|}
\hline Gene name & Forward sequence $5^{\prime}-3^{\prime}$ & Reverse sequence $5^{\prime}-3^{\prime}$ & $\begin{array}{c}\text { Melting } \\
\text { temperature }\left({ }^{\circ} \mathrm{C}\right)\end{array}$ & $\begin{array}{c}\text { Accession } \\
\text { number }\end{array}$ \\
\hline YWHAZ & ССТGСАTGAAGTСТGTAАСTGAG & TTGAGACGACCCTCCAAGATG & 60 & NM_003406 \\
\hline HPRT & TGACACTGGCAAAACAATGCA & GGTCCTTTTCACCAGCAAGCT & 55 & NM_000194.2 \\
\hline$S D H A$ & TGGGAACAAGAGGGCATCTG & CСАССАСТGСАТСАААTTCATG & 55 & NM_004168.2 \\
\hline
\end{tabular}


$25 \mu \mathrm{l}$ volumes consisting of $1 \mu \mathrm{l}$ of template cDNA, $12 \cdot 5 \mu \mathrm{l}$ of $2 \times$ QuantiFast SYBR Green PCR (Qiagen), $0.5 \mu \mathrm{M}$ forward primer, $0 \cdot 5 \mu \mathrm{M}$ reverse primer and $9 \mu \mathrm{l}$ nuclease-free water. Real-time PCR was performed on all samples using a Stratagene $\mathrm{Mx} 3000 \mathrm{P}$ using a fast cycling programme consisting of an initial PCR activation step of $5 \mathrm{~min}$ at $95^{\circ} \mathrm{C}$ followed by 40 cycles of denaturation at $95^{\circ} \mathrm{C}$ for $10 \mathrm{~s}$ and combined annealing and extension step of $60^{\circ} \mathrm{C}$ for $30 \mathrm{~s}$. Melt curve analysis was performed at $95-55^{\circ} \mathrm{C}$. A no-template control and reverse transcription negative control sample were included in all assays.

PCR efficiencies were determined from the standard curves and were $>97 \%$ for all genes. All standard curves were linear $\left(r^{2}>0.995\right)$ from $10^{7}$ to $10^{1}$ copies. For each gene, the sample threshold cycle $\left(C_{\mathrm{t}}\right)$ and hence copy number/ $\mu \mathrm{l}$ cDNA was determined from the standard curve using the MxPro software (Agilent). Normalisation of data was performed using geNorm software that calculated the normalisation factor of the reference genes for each sample (Vandesompele et al. 2002), data are expressed in arbitrary units.

\section{Western immunoblotting}

Normal term pregnancy $(n=10), \operatorname{PE}(n=10)$ placental tissues or high-RI $(n=6)$ and normal-RI $(n=6)$ early placental samples were homogenised in lysis buffer (CelLytic MT, Sigma-Aldrich) containing a protease inhibitor cocktail as per manufacturer instructions (Sigma-Aldrich). The protein concentration of the protein-containing supernatant was determined using a bicinchoninic acid protein assay (Pierce Biotechnology, Rockford, IL, USA). Each protein sample $(30 \mu \mathrm{g})$ was used for western immunoblotting. Proteins were first separated by SDS-PAGE and then transferred to polyvinylidene fluoride membranes (Immobilon P, Millipore, Watford, UK). Membranes were blocked overnight in $10 \%$ Marvel in $0.2 \%$ Tween Tris-buffered saline at $4{ }^{\circ} \mathrm{C}$. The following morning, membranes were washed and then incubated for $1 \mathrm{~h}$ in rabbit polycloncal anti-kisspeptin (Abcam, Cambridge, UK; ab80994; $10 \mu \mathrm{g} / \mathrm{ml}$ ), antiKISS1R (Abcam; ab100896; $1 \mu \mathrm{g} / \mathrm{ml}$ ) or anti- $\beta$ actin antibody (Abcam; ab8227; 1/2000), which was used as a loading control. Membranes were washed before $30 \mathrm{~min}$ incubation in HRP conjugated goat anti-rabbit IgG secondary antibody (Abcam; ab97080; 1:5000). Immunoreactivity was detected using AceGlow Ultra sensitive chemiluminescence substrate (PeqLab, Sarisbury Green, UK) according to the manufacturer's instructions. Membranes were visualised using Quantity One 4.2.1 image analysis software (Bio-Rad). Data were corrected for background and then normalised to $\beta$-actin expression.

\section{Statistical analysis}

All analyses were performed using SPSS for Windows version 17.0 (Chicago, IL, USA). The Kolmogorov-Smirnov test was used to assess the distribution of data. All data had a normal distribution and therefore between-group comparisons were made using a Student's $t$-test. The standard value of $P \leq 0 \cdot 05$ was considered significant. Unless otherwise stated all data are expressed as mean \pm S.E.M.

\section{Results}

Immunohistochemistry

KISS1- and KISS1R-positive immunolabellings were present in all samples examined. KISS1 protein expression was significantly reduced in PE placental samples $(1 \cdot 21 \pm 0 \cdot 20)$ compared with normal term pregnancy $(3 \cdot 72 \pm 0 \cdot 276$; $P<0 \cdot 001)$. There was also a significant reduction in KISS1 expression between early pregnancy $(6 \cdot 18 \pm 0 \cdot 384)$ and term normal pregnancy placenta $(P<0 \cdot 001 ;$ Fig. 1$)$. Placental KISS1R expression was found to be higher in $\mathrm{PE}$ $(3 \cdot 01 \pm 0 \cdot 138)$ than in normal term pregnancy $(1 \cdot 73 \pm 0 \cdot 125$; $P<0 \cdot 001)$. Protein expression of KISS1R was also found to be lower in term pregnancy placental samples than in early pregnancy samples $(4 \cdot 04 \pm 0 \cdot 199 ; P<0 \cdot 001$; Fig. 1$)$.
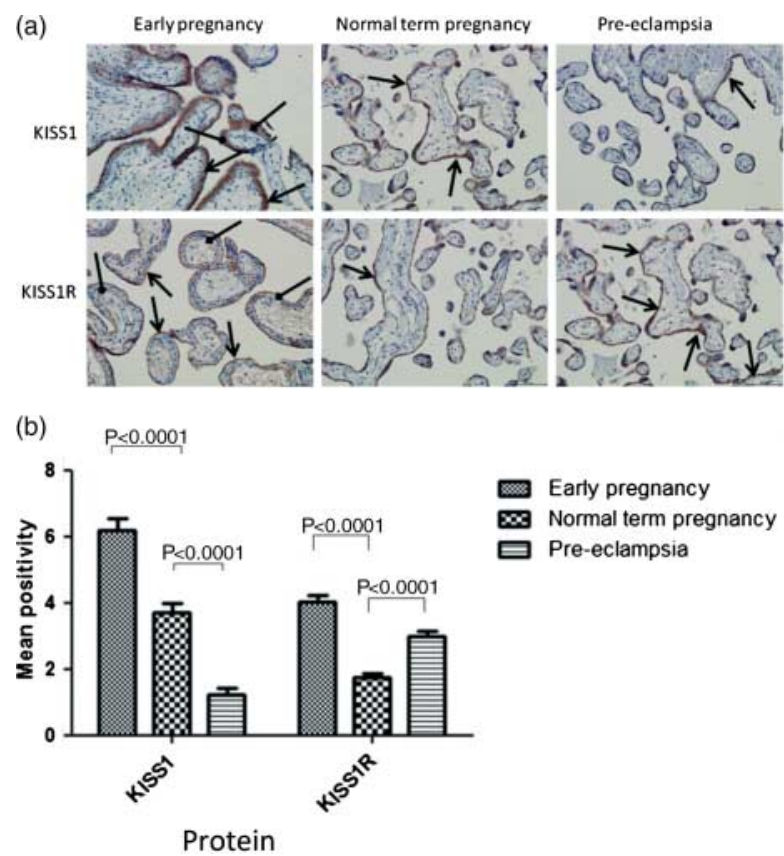

Figure 1 (a) Photomicrographs to show placental expression of KISS1 and KISS1R in early pregnancy, normal term pregnancy and PE. Staining was predominantly localised to syncytiotrophoblast cells (indicated with open headed arrow) with a small amount of staining present in villous cytotrophoblast cells (indicated with diamond headed arrow). Positive labelled cells appear brown; magnification $\times 200$. (b) Graph of immunohistochemical labelling for KISS1 and KISS1R. Data are expressed as mean \pm S.E.M. positivity. 


\section{Western immunoblotting}

Protein expression as determined by western immunoblotting also identified an increased expression of KISS1 in term normal pregnancy placenta $(20 \cdot 3 \pm 3 \cdot 31)$ compared with PE placental samples $(4 \cdot 9 \pm 0 \cdot 94 ; P<0 \cdot 001$, Fig. 2). Placental KISS1R expression was increased in PE (114 $\pm 3 \cdot 7)$ and term normal pregnancy $(24 \cdot 3 \pm 2 \cdot 81 ; P<0 \cdot 001$; Fig. 2$)$. Additionally, early pregnancy samples identified that women with high uterine artery RI (less spiral artery remodelling and a higher risk of developing PE) expressed lower levels of KISS1 protein $(39 \pm 4 \cdot 4)$ than did women with a normal uterine artery RI and a lower risk of developing PE (177.7 $\pm 6 \cdot 8 ; P<0 \cdot 001$; Fig. 3). KISS1R expression was also found to be higher in high-RI placental samples $(180 \cdot 7 \pm 6 \cdot 7)$ than in normal-RI placental samples $(84 \pm 5 \cdot 1 ; P<0 \cdot 001$; Fig. 3$)$.

\section{$m R N A$}

mRNA expressions for both KISS1 and KISS1R as assayed by qRT-PCR displayed similar expression patterns to that seen for protein expression (Fig. 4). mRNA expressions of the three reference genes $Y W H A Z, H P R T$ and $S D H A$ did not vary between groups. The highest levels of expressions for both $\operatorname{KISS} 1(2 \cdot 49 \pm 0 \cdot 144)$ and $\operatorname{KISS1R}(2 \cdot 33 \pm 0 \cdot 064)$ were found in early pregnancy placenta compared with normal term pregnancy $(P<0 \cdot 001$; Fig. 4). KISS1 expression was reduced in PE placental samples $(0 \cdot 286 \pm 0 \cdot 08)$ compared

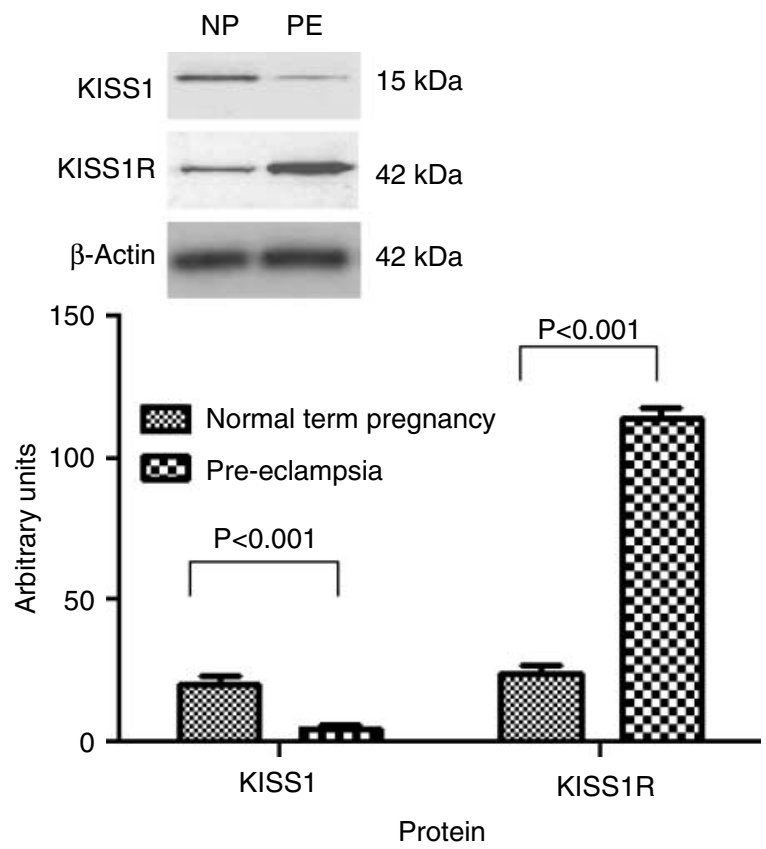

Figure 2 Graph to show protein expression levels determined by western immunoblotting in term normal pregnancy (NP) and PE. Photomicrographs show representative samples for each antibody. Data are shown as mean \pm S.E.M. relative expression normalised to $\beta$-actin.

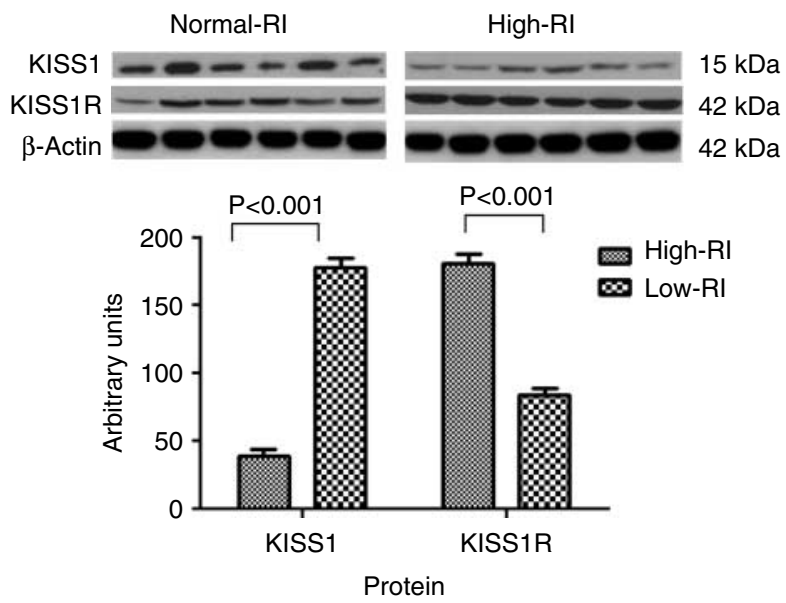

Figure 3 Graph and photomicrographs to show protein expression levels determined by western immunoblotting in early pregnancy placental samples from women with high (high-RI) and normal RI (normal-RI). RI was used as a proxy measure of the extent of uterine vessel remodelling, which is impaired in PE.

with term normal pregnancy $(0 \cdot 95 \pm 0 \cdot 17 ; P=0 \cdot 003$; Fig. 3$)$. However, expression of KISS1R mRNA was significantly higher in $\mathrm{PE}(1.57 \pm 0 \cdot 19)$ than in term normal pregnancy $(0 \cdot 80 \pm 0 \cdot 13 ; P=0 \cdot 003)$.

\section{Discussion}

This study demonstrates reduced expression of KISS1 and increased expression of KISS1R in PE compared with control term pregnancy at both the protein and mRNA levels. Additionally, this study has confirmed previous observations of highest levels of expression of both KISS1 and KISS1R in early pregnancy. The results of this study indicate that reduced expression of KISS1 and increased expression of KISS1R may be involved in the pathogenesis of PE due to alterations in expression at both mRNA and protein levels compared with normal pregnancy. It is interesting to note that in early pregnancies screened by uterine artery Doppler ultrasound as a proxy measure of the extent of uterine vessel remodelling (which is impaired in PE), there was also reduced KISS1 and increased KISS1R expressions in those with a high RI compared with those with normal RI, suggesting that these differences are apparent early on and at a stage at which the pathology of PE is becoming established.

The present finding of a reduction in placental KISS1 expression is in agreement with the reports of lower circulating levels in the first and second trimester of pregnancy in women who deliver small for gestational age neonates and who subsequently developed PE and/or intrauterine growth restriction and with the suggestion that KISS1 represents a suitable biomarker for PE (Smets et al. 2008, Armstrong et al. 2009, Logie et al. 2011). KISS1 was originally 
Early pregnancy

Normal term pregnancy

EPre-eclampsia

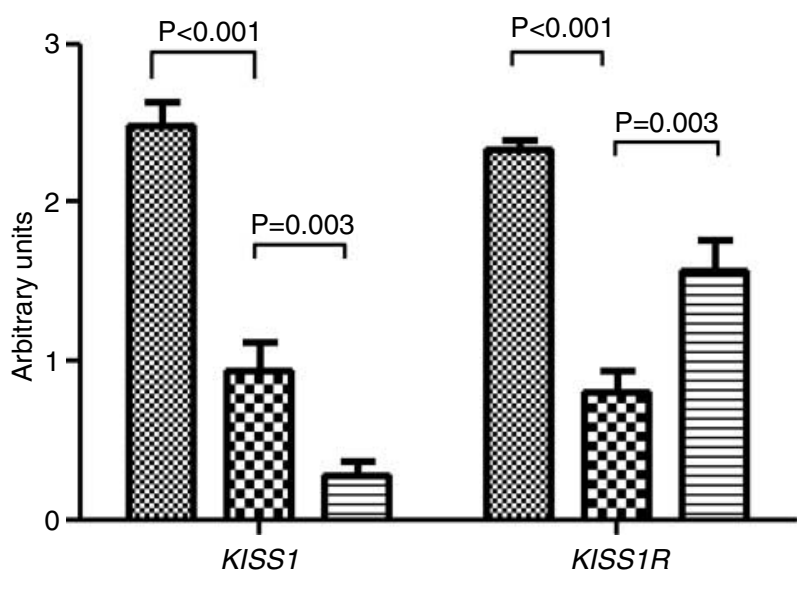

Gene

Figure 4 Graph to show mRNA expression of KISS1 and KISS1R as determined by qRT-PCR. Data are expressed as mean \pm S.E.M. arbitrary units calculated following normalisation of copy number using normalisation factor obtained from the three housekeeping genes YWHAZ, HPRT and SDHA.

identified due to its anti-metastatic properties and within full term placenta and in the trophoblast derived cell line HTR8/ Svneo Kp-10 has been shown to inhibit cell migration (Bilban et al. 2004, Roseweir et al. 2012). However, this finding has yet to be reproduced in early pregnancy placental samples. Furthermore, the current finding is in agreement with the recent report that has shown decreased expression of KISS1 in women with recurrent early pregnancy loss (Park et al. 2012), again indicating an important role for KISS1 in establishment of the placenta. The finding of reduced levels of KISS1 in PE may appear to contradict our understanding of the pathophysiology of PE, which is accepted to begin with inadequate trophoblast invasion. However, it has been suggested that lower levels of KISS1 within the placenta in pathological pregnancies may signal low invasive capacity, where reduced invasive capacity would be expected (Smets et al. 2008). Smets et al. describe how expression of kisspeptin is highest during the period of maximal trophoblast invasion and suggest that high invasive capacity is counteracted by the inhibitory effect of high levels of kisspeptin, and a low expression of kisspeptin signals low invasive capacity. Alternatively, smaller less invasive placentae may develop in PE, which have a reduced capacity to produce KISS1.

A further possible explanation for the decreased expression of KISS1 in the pathophysiology of PE may relate to the simultaneous increase in KISS1R, which may serve to maximise the activity of KISS1 and thereby inhibit trophoblast migration, which is crucial to the successful development of the placenta. In this manner the reduced expressions of both mRNA and protein of KISS1, which in itself would lead to a reduction in inhibition of cell migration, are negated via the higher levels of expression of KISS1R, thereby achieving higher activity levels of KISS1, resulting in increased inhibition of cell migration. KISS1 has also been shown to be angiostatic (Ramaesh et al. 2010) and therefore increased overall KISS1 activity due to increased expression of KISS1R may result in inhibition of angiogenesis within human placental vessels leading to the development of PE.

A second explanation for the observed reduction in KISS1 expression in placenta of women with PE may be that KISS1 expression is reduced as a result of the reduced trophoblast invasion during the early stages of pregnancy that leads to reduced expression of KISS1 as a mechanism to try to increase trophoblast invasion and placental development. A further possible explanation may be because the current study has examined KISS1, which will identify the smaller peptide products $\mathrm{Kp}-54, \mathrm{Kp}-14, \mathrm{Kp}-13$ and $\mathrm{Kp}-10$. To the best of the authors' knowledge, with the exception of Kp-10, which has been studied extensively (Bilban et al. 2004), the function of the other kisspeptin fragments in human placentation has not been described. Further functional studies are required to determine the exact functional effects of each of these biological active kisspeptins to examine if they all have the same function within the placenta.

Possible limitations of the present study are that the reduction in KISS1 and KISS1R expressions in PE may represent a secondary change rather than being responsible for the primary pathogenesis of $\mathrm{PE}$; however, the confirmation of higher levels of KISS1R and lower levels of KISS1 in early placenta pregnancy samples indicates that these findings are likely to be important in the early placental changes associated with PE. Furthermore, the present sample size is relatively small $(n=10)$ in each group and these findings need to be replicated in a much larger cohort to validate the present findings. Although mRNA and protein expressions mirrored each other, it is important to consider that altered expression does not necessarily correlate with altered function and therefore further functional studies are warranted. A further possible limitation of the study is the difference in gestational age at delivery between the term normal pregnancy and PE sample groups. The obstetric management for women with $\mathrm{PE}$ is delivery, which is frequently preterm, making it difficult to collect gestational age-matched samples of women who meet the ISSHP guidelines for diagnosis of PE at full term (Turner 2010).

This study shows altered expression of KISS1 and its receptor KISS1R in PE suggesting a role in the pathophysiological changes that occur in this disorder.

\section{Declaration of interest}

The authors declare that there is no conflict of interest that could be perceived as prejudicing the impartiality of the research reported.

www.endocrinology-journals.org 


\section{Funding}

P J W was supported by a Society for Endocrinology Early Career Grant and by The Wellcome Trust (grant number 088841/Z/09/Z).

\section{Acknowledgements}

We thank all the women who participated in this study and the midwives and doctors who assisted with sample collection.

\section{References}

Armstrong RA, Reynolds RM, Leask R, Shearing CH, Calder AA \& Riley SC 2009 Decreased serum levels of kisspeptin in early pregnancy are associated with intra-uterine growth restriction and pre-eclampsia. Prenatal Diagnosis 29 982-985. (doi:10.1002/pd.2328)

Bilban M, Ghaffari-Tabrizi N, Hintermann E, Bauer S, Molzer S, Zoratti C, Malli R, Sharabi A, Hiden U, Graier W et al. 2004 Kisspeptin-10, a KiSS-1/metastin-derived decapeptide, is a physiological invasion inhibitor of primary human trophoblasts. Journal of Cell Science 117 1319-1328. (doi:10.1242/jcs.00971)

Brown MA, Lindheimer MD, de Swiet M, Van Assche A \& Moutquin JM 2001 The classification and diagnosis of the hypertensive disorders of pregnancy: statement from the International Society for the Study of Hypertension in Pregnancy (ISSHP). Hypertension in Pregnancy 20 IX-XIV. (doi:10.1081/PRG-100104165)

Dhillo WS, Savage P, Murphy KG, Chaudhri OB, Patterson M, Nijher GM, Foggo VM, Dancey GS, Mitchell H, Seckl MJ et al. 2006 Plasma kisspeptin is raised in patients with gestational trophoblastic neoplasia and falls during treatment. American Journal of Physiology. Endocrinology and Metabolism 291 E878-E884. (doi:10.1152/ajpendo.00555.2005)

Hiden U, Bilban M, Knofler M \& Desoye G 2007 Kisspeptins and the placenta: regulation of trophoblast invasion. Reviews in Endocrine \& Metabolic Disorders 8 31-39. (doi:10.1007/s11154-007-9030-8)

Horikoshi Y, Matsumoto H, Takatsu Y, Ohtaki T, Kitada C, Usuki S \& Fujino M 2003 Dramatic elevation of plasma metastin concentrations in human pregnancy: metastin as a novel placenta-derived hormone in humans. Journal of Clinical Endocrinology and Metabolism 88 914-919. (doi:10.1210/jc.2002-021235)

Janneau JL, Maldonado-Estrada J, Tachdjian G, Miran I, Motte N, Saulnier P, Sabourin JC, Cote JF, Simon B, Frydman R et al. 2002 Transcriptional expression of genes involved in cell invasion and migration by normal and tumoral trophoblast cells. Journal of Clinical Endocrinology and Metabolism 87 5336-5339. (doi:10.1210/jc.2002-021093)

Logie JJ, Denison FC, Riley SC, Ramaesh T, Forbes S, Norman JE \& Reynolds RM 2011 Evaluation of kisspeptin levels in obese pregnancy as a biomarker for pre-eclampsia. Clinical Endocrinology 76 887-893. (doi:10.1111/j.1365-2265.2011.04317.x)

Luan X, Zhou Y, Wang W, Yu H, Li P, Gan X, Wei D \& Xiao J 2007 Association study of the polymorphisms in the KISS1 gene with central precocious puberty in Chinese girls. European Journal of Endocrinology 157 113-118. (doi:10.1530/EJE-07-0061)

Mead EJ, Maguire JJ, Kuc RE \& Davenport AP 2007a Kisspeptins are novel potent vasoconstrictors in humans, with a discrete localization of their receptor, $\mathrm{G}$ protein-coupled receptor 54, to atherosclerosis-prone vessels. Endocrinology 148 140-147. (doi:10.1210/en.2006-0818)

Mead EJ, Maguire JJ, Kuc RE \& Davenport AP 2007b Kisspeptins: a multifunctional peptide system with a role in reproduction, cancer and the cardiovascular system. British Journal of Pharmacology 151 1143-1153. (doi:10.1038/sj.bjp.0707295)

Melchiorre K, Wormald B, Leslie K, Bhide A \& Thilaganathan B 2008 First-trimester uterine artery Doppler indices in term and preterm pre-eclampsia. Ultrasound Obstetrics and Gynecology 32 133-137. (doi:10.1002/uog.5400)
Ohtaki T, Shintani Y, Honda S, Matsumoto H, Hori A, Kanehashi K, Terao Y, Kumano S, Takatsu Y, Masuda Y et al. 2001 Metastasis suppressor gene KiSS-1 encodes peptide ligand of a G-protein-coupled receptor. Nature 411 613-617. (doi:10.1038/35079135)

Park DW, Lee SK, Hong SR, Han AR, Kwak-Kim J \& Yang KM 2012 Expression of Kisspeptin and its receptor GPR 54 in the first trimester trophoblast of women with recurrent pregnancy loss. American Journal of Reproductive Immunology 67 132-139. (doi:10.1111/j.1600-0897.2011.01073.x)

Poon LC, Staboulidou I, Maiz N, Plasencia W \& Nicolaides KH 2009 Hypertensive disorders in pregnancy: screening by uterine artery Doppler at 11-13 weeks. Ultrasound Obstetrics and Gynecology 34 142-148. (doi:10.1002/uog.6452)

Prefumo F, Sebire NJ \& Thilaganathan B 2004 Decreased endovascular trophoblast invasion in first trimester pregnancies with high-resistance uterine artery Doppler indices. Human Reproduction 19 206-209. (doi:10.1093/humrep/deh037)

Ramaesh T, Logie JJ, Roseweir AK, Millar RP, Walker BR, Hadoke PW \& Reynolds RM 2010 Kisspeptin-10 inhibits angiogenesis in human placental vessels ex vivo and endothelial cells in vitro. Endocrinology 151 5927-5934. (doi:10.1210/en.2010-0565)

Roa J, Aguilar E, Dieguez C, Pinilla L \& Tena-Sempere M 2008 New frontiers in kisspeptin/GPR54 physiology as fundamental gatekeepers of reproductive function. Frontiers in Neuroendocrinology 29 48-69. (doi:10.1016/j.yfrne.2007.07.002)

Roseweir AK, Katz AA \& Millar RP 2012 Kisspeptin-10 inhibits cell migration in vitro via a receptor-GSK3 beta-FAK feedback loop in HTR8SVneo cells. Placenta 33 408-415. (doi:10.1016/j.placenta.2012.02.001)

de Roux N, Genin E, Carel JC, Matsuda F, Chaussain JL \& Milgrom E 2003 Hypogonadotropic hypogonadism due to loss of function of the KiSS1derived peptide receptor GPR54. PNAS 100 10972-10976. (doi:10.1073/ pnas.1834399100)

Seminara SB, Messager S, Chatzidaki EE, Thresher RR, Acierno JS Jr, Shagoury JK, Bo-Abbas Y, Kuohung W, Schwinof KM, Hendrick AG et al. 2003 The GPR 54 gene as a regulator of puberty. New England Journal of Medicine 349 1614-1627. (doi:10.1056/NEJMoa035322)

Smets EM, Deurloo KL, Go AT, van Vugt JM, Blankenstein MA \& Oudejans CB 2008 Decreased plasma levels of metastin in early pregnancy are associated with small for gestational age neonates. Prenatal Diagnosis 28 299-303. (doi:10.1002/pd.1969)

Turner JA 2010 Diagnosis and management of pre-eclampsia: an update. International Journal of Women's Health 2 327-337. (doi:10.2147/IJWH.S8550)

Vandesompele J, De Preter K, Pattyn F, Poppe B, Van Roy N, De Paepe A \& Speleman F 2002 Accurate normalization of real-time quantitative RT-PCR data by geometric averaging of multiple internal control genes. Genome Biology 3 RESEARCH0034. (doi:10.1186/gb-2002-3-7research0034)

Whitley GS, Dash PR, Ayling LJ, Prefumo F, Thilaganathan B \& Cartwright JE 2007 Increased apoptosis in first trimester extravillous trophoblasts from pregnancies at higher risk of developing preeclampsia. American Journal of Pathology 170 1903-1909. (doi:10.2353/ajpath.2007. 070006)

Williams PJ, Mistry HD, Innes BA, Bulmer JN \& Pipkin FB 2010 Expression of AT1R, AT2R and AT4R and their roles in extravillous trophoblast invasion in the human. Placenta 31 448-455. (doi:10.1016/j.placenta.2010. 02.014)

Yan C, Wang H \& Boyd DD 2001 KiSS-1 represses 92-kDa type IV collagenase expression by down-regulating NF-kappa B binding to the promoter as a consequence of Ikappa $\mathrm{B} \alpha$-induced block of $\mathrm{p} 65 / \mathrm{p} 50$ nuclear translocation. Journal of Biological Chemistry 276 1164-1172. (doi:10.1074/ jbc.M008681200)

Received in final form 2 April 2012

Accepted 23 April 2012

Made available online as an Accepted Preprint 23 April 2012 